\title{
The Predictive Impact of Cultural Values and Ideology on Employer-Employees Relations in Contemporary Nigeria
}

\author{
Adigun, Abel. 0. \\ Department of Business Administration \\ Bell University of Technology Ota, Nigeria
}

\begin{abstract}
This study investigated the predictive impact of cultural values and ideology on employer-employees relations in contemporary Nigeria. Using a descriptive survey research design, simple random sampling technique was used to select four hundred employer-employees from ten manufacturing organisations in Ibadan, Nigeria. A self-constructed questionnaire $(0.84)$ was used to collect relevant data for the study. Two research questions were answered and two hypotheses tested at 0.05 level of significance. Data were analysed using Multiple Regression and Pearson Product Moment Correlation statistical tool. There was significant relationship between the independent variables and the dependent variable. Also, the independent variables accounted for $45.5 \%$ of the total variance on the predictive impact of cultural values and ideology on employer-employees relations in contemporary Nigeria. In order of magnitude, of the contribution: ideology has more influence on employer-employees relations $(\beta=0.373, t=2.246, P<0.05)$ followed by cultural values $(\beta=0.156, t$ $=1.668, P<0.05)$. Therefore, Management should ensure appropriate work orientation is given to workers so that they will be conscious of their organizations cultural values and ideological philosophy as to support the growth of the organization.
\end{abstract}

Key Words: Cultural values, Ideology, Employer-Employee Relations, Organisation, Ibadan.

\section{INTRODUCTION}

The condition of service, terms of engagement, quality of life and work relationship pattern that exists in an organisations environment is paramount to the realisation of high productivity, sustainability and harmony. This influences the performance of any organisation in all ramifications. However, attaining harmonious employer-employee relationship that is conflict free is often a challenge to organisation(s). This makes possible factors such as cultural values and ideology that can affect employer-employee relationship an important issue of discuss in this contemporary time considering the fact that employer-employees synergy is central to attaining an effective operational process and actualisation of organisational goals and objectives.

According to Hsieh (2008) the imprecise nature of the inter-play of organisations cultural values and ideology that exists between employer and employee has spurred interest in field of organisational management. The terms refer to the perceptions of employer and employee about what their mutual obligations are towards each other. Their effect focuses on what drives day-to-day behaviour - the unwritten rules and expectations that govern employeremployees interaction, the 'way things are done in an organisation. These implicit signals can prove much more important in the management of the employment relationship than any 
piece of paper as the moral bargain of work revolves around understandings of obligations, expectations and promises.

According to Penna research report (2007) organisations cultural value and ideology could make the work environment and experience meaningful to employer and employees. Meaning at work has the potential of bringing employers and employees closer together to the benefit of both where employees experience a sense of community, the space to be themselves and the opportunity to make a contribution. Employees want to work in the organizations in which they find meaning at work. Thus, White (2006) study found that almost two third's (60\%) of the surveyed employees want more opportunities to grow forward to remain satisfied in their jobs. Also, White (2006) reports that strong employer-employee relationship is a crucial ingredient in the employee engagement and retention formula.

\section{REVIEW OF LITERATURE}

Employment relationship refers to the relationships that exist between employers and employees in their working environment, these relationships may be formal as in contracts of employment and procedural agreements (Gallie, 1998). These relationships could also be informal as in psychological contract, which states 'certain assumptions and expectations about what managers and employer have to offer and are willing to deliver' (Armstrong, 2005). Employees are a significant part of the employment relationship but they are not to be seen as commodities or just another factor of production as it is assumed under the traditional orthodox theories of supply and demand (Budd \& Bhave, 2006).

Employer-employees relationship is a dynamic synergy in human resources management with the collaborative aim of gaining competitive advantage over competitors through the strategic development of a highly committed and capable workforce using an integrated array of cultural, ideological, structural and personnel techniques (Storey, 2001). Armstrong (2005) contends that understanding and appraising the efficacy of cultural values and ideological principles in human resources management is strategic to effective functioning of an organisation's human potentials in which every aspect of its operations. Thus, the knowledge of the factors that impact on harmonious employer-employee relationship in Nigeria is becoming increasingly critical to the way businesses are done in Nigeria and ultimately their success. Hence, the way to get things done cannot be divorced from local values, customs, and the overall external cultural environment. Nigeria according to Fajana (2009) is one of the African countries troubled by abundant labour and scare talent. Attracting, developing, deploying and retaining best talents had become a challenge. That is why Fajana and Ige (2009) argued that the desire for top performance has driven the need for effective employeremployee relationship.

Adigun (2013) reports that employer-employees relationship is a complex experience in which many individuals, other variables or elements in an organisation have a role to play and the role of any one party in organization is affected by the role of the other. This suggests the fact that employer-employees relationship in organisation(s) involves a range of complex patterns of interactions between different work-related groups such as trade unions and employers at organisational level, and the state and its agencies in the regional as well as the national levels (Rose, 2004). Also, Blyton and Turnbull (2004) posited that employer-employees relationship portrays the distinctive characteristics of all employment relationships either individual relationships or collective relationships. However, they contend that understanding employeremployees relationships involves locating it within the broader nature of the economic activity involved and also taking into consideration the structural basis of the probable conflict and 
accommodation between employee and employer; the persuasion as well as the manipulation of the larger society on employment relations is also important. In essence, "the nature of employment relations in any organisation should be seen in relation to wider socio-economic, political and legal structure" (Debrah \& Mmieh, 2009).

Organisations globally, Nigeria inclusive operates based on specified cultural norms that guides their everyday operational activities. Such organisations culture has values attached to it and it helps propel organisations ability to attain their goals and objectives. The values attach to culture that exist in an organisation help determines mode of operation, devolution of power, authority, communication, relationship, conflict management, manner of bargaining, among others. This implies that organisational culture are basically behaviour and expressed ways of life that guides valued relationship that exist in an organisation to enhance its functionality and productivity.

The value attached to efficacy of cultural norms in organisation makes the understanding of organisations cultural values an important issue of discuss in both management and management practices literature (Denison, 1990; Lau \& Ngo, 1996). It has also been variously defined as the history of an organisation or what allows employees to understand their workplace, it also makes the employees to make sense of work activities and to relate them to daily events (Porter, 1990). It also forms one of the basis for competitive advantage (Deal \& Kennedy, 1988); it helps in determining the effectiveness of a company (Denison, 1990); it is important in developing high performance amongst staff (O" Reilly, 1989) and also helps in increase loyalty of staff to the organisation (Porter, 1990). Also, Olusoji, Adediji and Owoyemi (2012) contended that culture is the acquired knowledge that people use to interpret experience and to generate social behaviour, they further suggest that culture is shared by members of a community, organisation or a group and that through culture, values and attitudes are formed which invariably shape individuals as well as group behaviour. Culture to them is learned through education, socialisation and experience and it is passed from one generation to another; therefore it can be said to be enduring.

Beal and Begin (1982) remark that every human society and culture creates some kind of an industrial relations system or system of relations between the people who head organizations and direct its activities and those who do the work. Put in another way, the relationship between workers and those they work for is as old as human society itself. But this relationship has changed in accordance with prevailing socio-political and economic settings. The relationship has variously manifested in history as that between slave and master, between the serf and the baron of feudal societies, between the master and the workman of the industrial revolution era, and between the employee and employer of the present day.

The writings of Karl Marx (1818-1883), were very critical to the development of labour movement. His writings elevated labour by arguing that the capitalist's wealth is created by exploitation of surplus labour of the workman. Marx advocated that for the exploitation of labour to cease, the workers must seize and own the means of production. Marx's thesis and the theoretical and practical commitment of his followers, led to the great socialist revolution and labour union movements that dominated the politics and economic thinking of the greater part of 20th century. The outcome was the bipolar ideological world in which countries aligned along the two blocs of capitalism and socialism. The presence of labour unions was felt not only in countries that professed socialism but also in core capitalist ones.

The following research questions and hypothesis were answered in the study: 


\section{Research Questions}

1. To what extent does organisations cultural values and ideology impact on employeremployees relationship

2. What is the relative impact of organisations cultural values and ideology on employeremployees relationship?

\section{Research Hypothesis}

There is no significant relationship between organisations cultural values and employeremployees relationship

There is no significant relationship between organisations ideology and employer-employees relationship

\section{Design and Participants}

\section{METHODOLOGY}

This study adopted a descriptive survey research design of ex-post facto type. The population comprised of employer-employees of manufacturing organisations in Ibadan, Nigeria.

\section{Sample and Sampling Technique}

The samples for the study consist of 400 employer and employees randomly selected through the simple random sampling technique from ten randomly selected manufacturing industries in Ibadan Nigeria.

\section{Instrumentation}

A self constructed questionnaire was used for data collection for this study. The questionnaire is divided into four sections comprising (A, B, C, \& D) Section A has items on personal demographic variables; Section $B$ has ten items on employer-employees relationship: For example it has items such as; Worker work as a team; workers are giving feedback on why they are promoted or not promoted; workers welfare is taken serious etc; Section $\mathrm{C}$ is on organisations cultural value and it has six items. For example it has items such as; Workers are expected to report direct to their supervisor; Information is passed from management through supervisors to subordinates etc, Section D has six items on organisations ideology for example it has items such as; Discussions are made based on the principle of collective bargaining, productivity is enhanced through training etc. The questionnaire is structured on a likert scale format and it has internal reliability coefficient of 0.82 obtained through a test-re-test procedure.

\section{Procedure}

The researchers obtained permission from the management of the manufacturing industries used for the study. The consent of the participants were equally sought and obtained. After the consent of the participants was obtained, the researcher administered copies of the instrument with explanation on how to complete them and the purpose of the research.

\section{Method of Data analysis}

Data were analysed with multiple regression and Pearson Product Moment Correlation statistical tools at 0.05 level of significance.

\section{Result}

To what extent does organisations cultural values and ideology impact on employer-employees relationship 
Table 1: Regression summary table showing the extent to which organisations cultural values and ideology impact on employer-employees relationship

\begin{tabular}{|llllll}
\hline $\mathrm{R}=.591$ & & & & \\
$\mathrm{R}^{2=} \cdot 473$ & & & & \\
Adj $\mathrm{R}^{2=} .455$ & & & & \\
$\begin{array}{l}\text { Std Error=11.516 } \\
\text { Source }\end{array}$ & Df & Sum squares (ss) & Mean square & F-Ratio & Sig \\
& & & & & \\
Regression & 2 & 38681.126 & 19340.563 & 362.971 & .000 \\
Residual & 397 & 21153.861 & 53.284 & & \\
Total & 399 & 59834.987 & & &
\end{tabular}

The result on Table 1 revealed that organisations cultural values and ideology impact on employer-employees relationship with a joint contributing impact of $45.5 \%$. The composite effect of the independent variables as jointly contributive on employer-employees relationship are revealed as thus, $\mathrm{R}=.591, \mathrm{R} 2=.473$, Adj. $\mathrm{R} 2=.455$ and Std. error of estimate 11.516 . The result of the multiple regression analysis produced an F-Ratio $(2 / 397)=362.971$ which was significant at $\mathrm{p}<0.05$ alpha level.

What is the relative impact of organisations cultural values and ideology on employeremployees relationship?

Table 2: Showing the relative impact of organisations cultural values and ideology on employeremployees relationship

\begin{tabular}{|llllll|}
\hline Variables & B & Std. Error & Beta & t & Sig \\
& 43.264 & 4.421 & & 8.136 & .000 \\
Cultural Values & .325 & .174 & .156 & 1.668 & .341 \\
Ideology & .438 & .191 & .373 & 2.246 & .004 \\
\hline
\end{tabular}

Table 2 highlights the level of contribution of cultural values and ideology on employeremployees relationship. The table revealed the magnitude of each independent variable contribution on the dependent variable. Thus, Table 2 showed that ideology had more impact on employer-employees relationship. The t-observed for each of the variables attests to this fact.

Ho1: There is no significant relationship between organisations cultural values and employeremployees relationship

Table 3: PPMC summary table showing significant relationship between organisations cultural values and employer-employees relationship

\begin{tabular}{|l|l|l|l|l|l|l|}
\hline Variables & $\mathrm{N}$ & Mean & SD & R & df & p \\
\hline $\begin{array}{l}\text { Employer-Employee } \\
\text { Relationship }\end{array}$ & 400 & 33.26 & 7.066 & 0.294 & 398 & sig \\
\hline Cultural Values & 400 & 22.06 & 4.681 & & & \\
\hline
\end{tabular}

Table 3 shows that the variable cultural value correlates significantly with employeremployees relationship, $\mathrm{r}(398)=0.294, \mathrm{p}<.05$. The mean and standard deviation for cultural value was 22.06 and 4.681 respectively. With this result, the Ho: is thus, rejected.

Ho2: There is no significant relationship between organisations ideology and employeremployees relationship 
Table 4. PPMC summary table showing significant relationship between organisations ideology and employer-employees relationship

\begin{tabular}{|l|l|l|l|l|l|l|}
\hline Variables & $\mathrm{N}$ & Mean & SD & $\mathrm{R}$ & $\mathrm{df}$ & $\mathrm{p}$ \\
\hline $\begin{array}{l}\text { Employer-Employees } \\
\text { Relationship }\end{array}$ & 400 & 33.26 & 7.066 & 0.325 & 398 & sig \\
\hline Organisations Ideology & 400 & 30.10 & 8.106 & & & \\
\hline
\end{tabular}

Table 4 shows that the variable organisations ideology correlates positively with employeremployees relationship, $r(398)=0.325, \mathrm{p}<.05$. The mean and standard deviation for organisations ideology was 30.10 and 8.106 respectively. With this result, the Ho: is thus, rejected.

\section{DISCUSSION OF THE FINDINGS}

Research Question One seeks to find out what extent organisations cultural values and ideology impact on employer-employees relationship. The result of the study revealed that organisations cultural values and ideology impact on employer-employees relationship with a joint contributing impact of $45.5 \%$ and the result of the multiple regression analysis produced an F-Ratio $(2 / 397)=362.971$ which was significant at $\mathrm{p}<0.05$ alpha level. This development is an indication that organisations thrive better if they have well established culture and ideological principles that ensures equity, collective responsibility and management by objective. This influences the performance of any organisation in all ramifications. This is consistent with Penna research report (2007) indicating that organisations cultural value and ideology could make the work environment and experience meaningful to employer and employees. Meaning at work has the potential of bringing employers and employees closer together to the benefit of both where employees experience a sense of community, the space to be themselves and the opportunity to make a contribution. Employees want to work in the organizations in which they find meaning at work. Thus, White (2006) study found that almost two third's (60\%) of the surveyed employees want more opportunities to grow forward to remain satisfied in their jobs. Also, White (2006) reports that strong employer-employee relationship is a crucial ingredient in the employee engagement and retention formula.

Research Question Two seek to find out the relative impact of organisations cultural values and ideology on employer-employees relationship? The findings of the study showed that ideology had more impact on employer-employees relationship. The t-observed for each of the variables attests to this fact. Ideology is a strong factor that often influences people's behaviour positively or negatively. For example the ideological principle of, capitalism, collective bargaining, management by objective, principles of division of labour, etc is often used to the advantage of either the employer or the employee. This implies that ideology gives employer or employees a directional path to follow in dispensing of their daily operational activities. This corroborates Hsieh (2008) affirmation that a well appraised ideological philosophy is much more important in the management of employment relationship than any piece of paper as the moral bargain of work revolves around understandings of obligations, expectations and promises. Also, this finding is in line with Armstrong (2005) report of the fact that understanding and appraising the efficacy of organisations ideological principles in human resources management is strategic to effective functioning of an organisation's human potentials in every aspect of its operations.

Hypothesis one states that there is no significant relationship between organisations cultural values and employer-employees relationship. The result of the study revealed that cultural values correlates significantly with employer-employees relationship, $r(398)=0.294, p<.05$. With this result, the Ho: is thus, rejected. The reason for this could be appraised from the point 
of view that culture is the way of life of an organisation thus, the value attached to the efficacy of cultural norms in organisation is fundamental to their operations (Denison, 1990; Lau \& Ngo, 1996). It also forms one of the basis for competitive advantage (Deal \& Kennedy, 1988); it helps in determining the effectiveness of a company (Denison, 1990); it is important in developing high performance amongst staff (O" Reilly, 1989) and also helps in increase loyalty of staff to the organisation (Porter, 1990). Also, Olusoji, Adediji and Owoyemi (2012) contended that culture is the acquired knowledge that people use to interpret experience and to generate social behaviour, they further suggest that culture is shared by members of a community, organisation or a group and that through culture, values and attitudes are formed which invariably shape individuals as well as group behaviour.

Hypothesis Two states that there is no significant relationship between organisations ideology and employer-employees relationship. The findings of the study indicated that organisations ideology correlates positively with employer-employees relationship, $r(398)=0.325, p<.05$. With this result, the Ho: is thus, rejected. This indicates that organisations ideology is pertinent to operational interaction and employer-employees commitment to ensuring that they work as a team to attain organisational goals, objectives and sustainability. Thus, Adigun (2013) reports that employer-employees relationship is a complex experience in which many individuals, other variables or elements in an organisation have a role to play and the role of any one party in organization is affected by the role of the other. This suggests the fact that employer-employees relationship in organisation(s) involves a range of complex patterns of interactions between different work-related groups such as trade unions and employers at organisational level, and the state and its agencies in the regional as well as the national levels (Rose, 2004). Also, Blyton and Turnbull (2004) posited that employer-employees relationship portrays the distinctive characteristics of all employment relationships either individual relationships or collective relationships. However, they contend that understanding employeremployees relationships involves locating it within the broader nature of the economic activity involved and also taking into consideration the structural basis of the probable conflict and accommodation between employee and employer (Debrah \& Mmieh, 2009).

\section{IMPLICATION OF STUDY}

The findings of this research provide reasonable information that can be applied in organisational practice, human resources management and the understanding of employeremployee relationship. Thus, this study has brought to limelight the fact that attaining harmonious employer-employee relationship that is conflict free is often a challenge to organisation(s). This makes possible factors such as cultural values and ideology that can affect employer-employee relationship an important issue of discuss in this contemporary time considering the fact that employer-employees synergy is central to attaining an effective operational process and actualisation of organisational goals and objectives. Thus, employeremployees relationship is a dynamic synergy in human resources management with the collaborative aim of gaining competitive advantage over competitors through the strategic development of a highly committed and capable workforce using an integrated array of cultural, ideological, structural and personnel techniques (Storey, 2001).

\section{CONCLUSION}

Cultural values and ideology are two important factors that could impact on organisations ability to be functionally productive and sustainable. It therefore implies that industrial harmony is attainable when positive employer-employee relationships exist. Thus, employeremployee should work as a team and give every individual a sense of belongingness. This would further help organisations attain their goals and objectives. 


\section{RECOMMENDATIONS}

Based on the findings of this study, the researcher wishes to make the following recommendations:

Management should ensure appropriate work orientation is given to workers so that they will be conscious of their organizations cultural values and ideological philosophy as to support the growth of the organization.

Management should expose workers to training that would enable them develop the required skills that would make them functional and efficient

The line of communication should be made in such a way that individuals will be aware of developments in the organization and not kept in the dark as to prevent gossip that is injurious to organizational growth and development.

\section{References}

Adigun A. O. (2013): The Implications of Social Democracy on Industrial Relations in Nigeria: Journal of Emerging Trends in Economics and Management Sciences (JETEMS) 5(1):26-31

Armstrong, M. (2005). Human resources management practice. (9th Ed.). London: Kogan Page.

Beal, E.F, and Begin, J.P. (1982).The Practice of Collective Bargaining, Homewood, Illinois: Richard D. Irwin Incorporation.

Blyton, P and Turnbull P, (2004), „The Dynamics of Employee Relations, “ Basingstroke: Macmillan.

Budd, J.W., \& Bhave, D. (2006). Values, Ideologies, and frames of reference in employment relations. Industrial Relations Center, University of Minnesota. Retrieved from http:// www.legacy-irc.csom.umn.edu.

Deal, T. and Kennedy, A. (1988), „Corporate Cultures: The Rites and Rituals of Corporate Life." Penguin Books, London.

Debrah, Y. A. \& Mmieh, F. (2009), „Employment relations in small-and medium-sized enterprises: insights from Ghana", The International Journal of Human Resource Management, 20(7):1554-1575.

Denison, D. R. (1990), „Corporate Culture and Organisational Effectiveness", Wiley, New York, NY.

Fajana, S. (2009) HR Management in Africa: The Social and Economic Framework, Personalfuhrung, 7, pp. 8086

Fajana, S. and Ige, A. Y. (2009) Globalisation and International Labour Mobility: An in-depth study of the Nigerian Health Sector, Conference of Marco Biangi Foundation. Modena / Italy.

Gallie, D. (1998). Restructuring the employment relationship. Oxford: Oxford University Press.

Hsieh, N. (2008): Survey Article: Justice in Production, The Journal of Political Philosophy, Volume 16, Number 1, pp.72-100.

Lau, C. M. and Ngo, H.Y. (1996), „One Country, many Cultures: Organisational Cultures of Different Country Origins", International Business Review, 5(5):469-486.

O" Reilly, C.A. (1989), „Winning Through Innovation“, in Tushman, M. (Ed.) Readings in the Management of Innovation, Pitman, Boston, M.A.

Olusoji J. G., Adediji, O, \& Owoyemi, O. (2012): Religion; the Forerunner of Organisational Culture: The Case of Quakerism in the Employment/Industrial Relations Practice of John and George Cadbury: International Journal of Business and Social Science Vol. 3 No. 11;

Porter, M. E. (1990), „The Competitive Advantage of Nations", Macmillan, London.

Penna (2007). Meaning at Work Research Report. [Online] Available: http:// www. Epenna.com/newsopinion/research.aspx (November10, 2008) 
Rose, Ed (2004), „Employment Relations“, Prentice Hall.

Storey, J. (2001) Introduction: From Personnel Management to Human Resource Management, A critical Text, Thomson Learning. London.

White, B. (2008). The Employee Engagement Equation in India. Presented by BlessingWhite and HRAnexi. [Online] Available: www.blessingwhite.com (November 15, 2008) 